
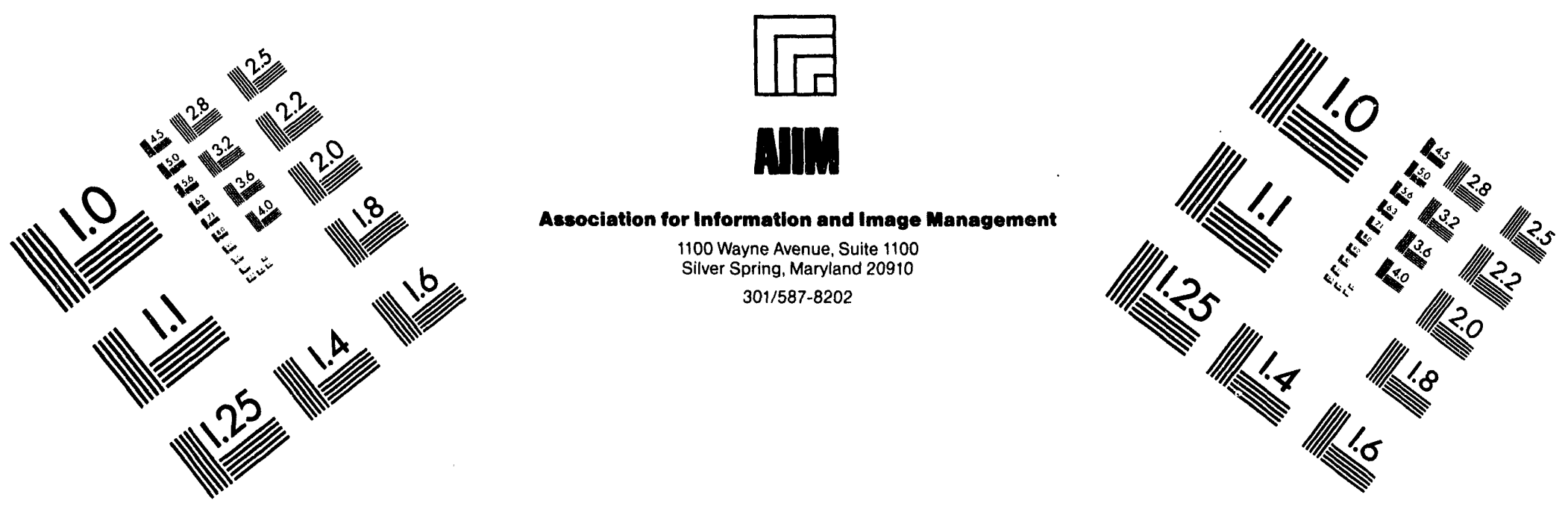

\title{
Centimeter
}

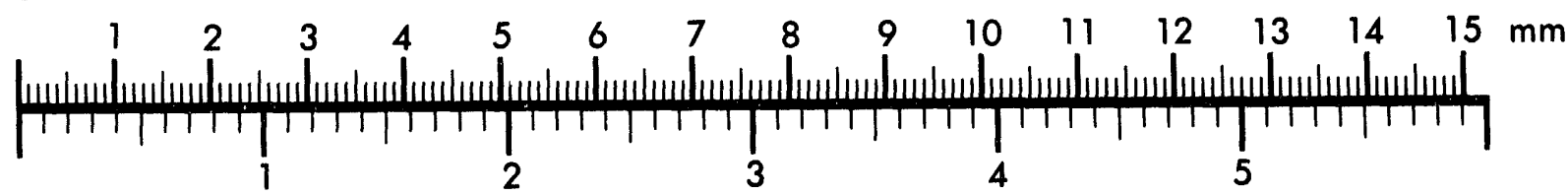
Inches
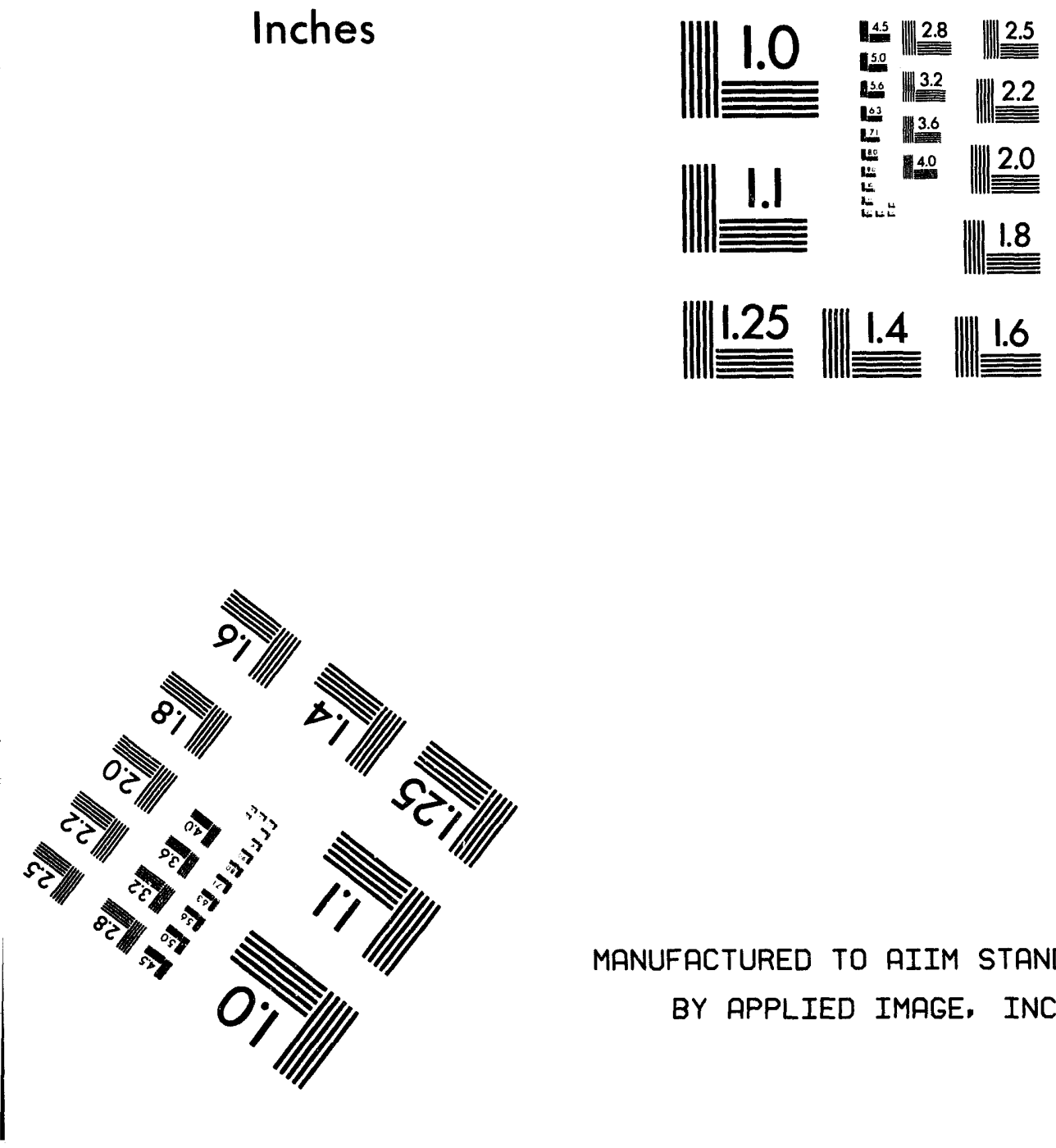

MANUFACTURED TO AIIM STANDARDS BY APPLIED IMAGE, INC.

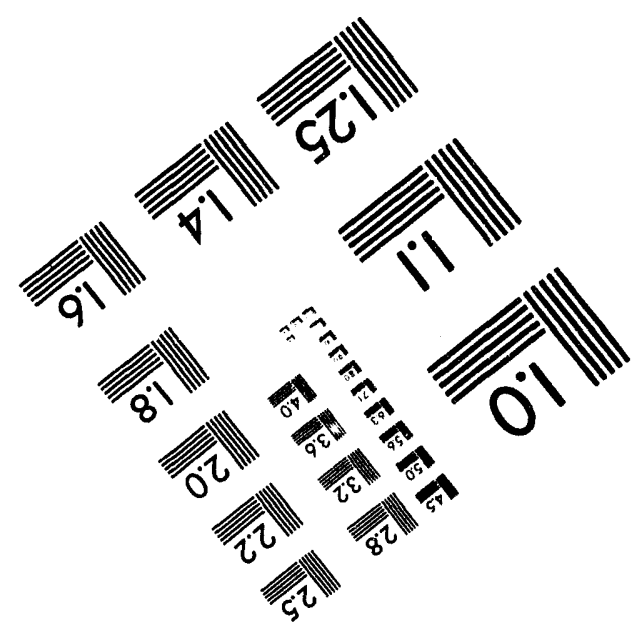



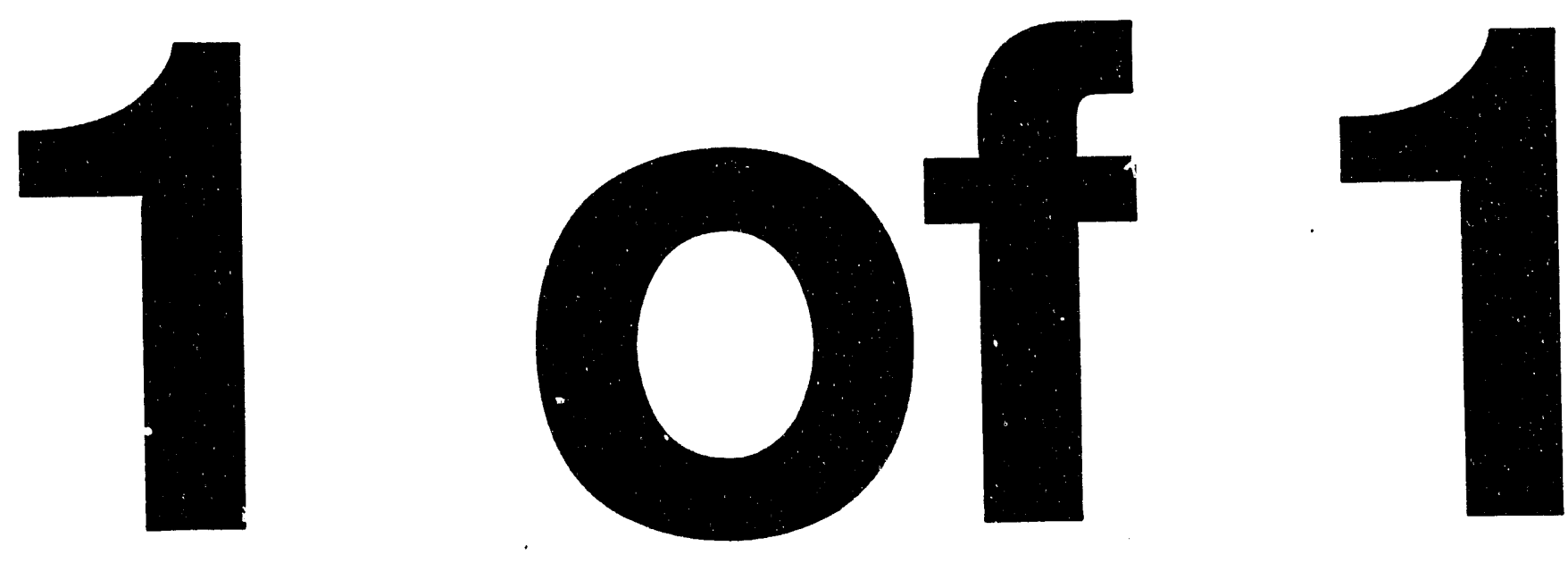


$$
\text { CONF- } 921142--11
$$

\title{
READINESS THROUGH RESEARCH
}

\section{PHYSICAL AND THERMAL PROPERTIES AND LEACHING CHARACTERISTICS OF A BENEFICIATED EASTERN OIL SHALE HYDRORETORTED IN THE PFH PROCESS}

\author{
by \\ Michael C. Mensinger \\ Institute of Gas Technology \\ Jeffry S. Budiman \\ Illinols Institute of Technology
}

Paper Presented at the

1992 EASTERN OIL SHALE SYMPOSIUM

Lexington, Kentucky

November 17-20, 1992

\section{INSTITUTE OF GAS TECHNOLOGY}

3424 South State Street? Chicago, IIlinols 60616

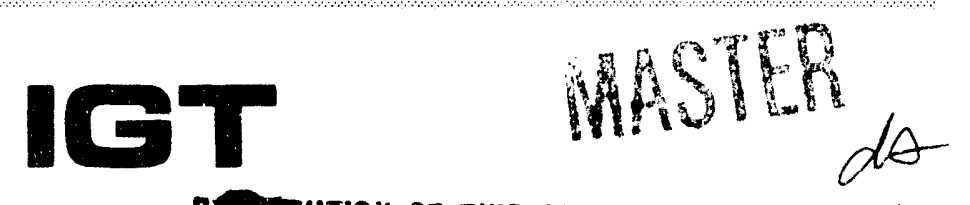




\title{
PHYSICAL AND THERMAL PROPERTIES AND LEACHING CHARACTERISTICS OF A BENEFICIATED EASTERN OIL SHALE HYDRORETORTED IN THE PFH PROCESS
}

\author{
Mr. Michael C. Mensinger \\ Institute of Gas Technology \\ Chicago, Illinois 60616-3896 \\ Dr. Jeffry S. Budiman \\ Department of Civil Engineering \\ Illinois Institute of Technology \\ Chicago, Illinois 60616-3896
}

\begin{abstract}
The preferred feedstocks for the Institute of Gas Technology's (IGT) Pressurized Fluidized-Bed Hydroretorting (PFH) process are beneficiated Eastern U.S. oil shales. After hydroretorting, the beneficiated shale is combusted to generate process and export power. Before hydroretorting and after combustion the shale will be stored in large embankments. The design and characteristics of these embankments depends on the physical, thermal, and leaching properties of the raw and spent shales.
\end{abstract}

IGT and the Illinois Institute of Technology conducted tests to determine the physical and thermal properties and leaching characteristics of samples of beneficiated and thermally processed Alabama shale. The physical and thermal properties determined include permeability, compressibility, compactability, consolidation, shear stress, cohesion, thermal conductivity, and liquid and plastic limits. Tests were conducted on samples of raw, hydroretorted, hydroretorted and combusted (H\&C), and hydroretorted and agglomerated (H\&A) beneficiated shale.

The results show that the physical properties of raw and thermally processed beneficiated shale are considerably different. Leachability test results show that none of the thermally processed shale samples exhibited the toxicity characteristic (per the Toxicity Characteristic Leaching Procedure (TCLP)]. Combustion and agglomeration reduced the levels of metals leached from the H\&C and H\&A shale samples during TCLP tests. Overall, storage of raw and spent beneficiated shales in embankments will not result in significant environmental impacts.

\section{Introduction}

The Institute of Gas Technology (IGT) is deveioping the pressurized, fluidized-bed hydroretorting (PFH) process for producing oil from shales in the Eastern U.S. The overall program, funded by the U.S. Department of Energy (DOE), includes a task that addresses environmental concerns of oil shale processing. The objectives of this task are to obtain environmental data relating to $\mathrm{PFH}$ and shale beneficiation and to estimate the potential environmental impacts of the integrated PFH process. During the 3-year program, IGT conducted physical and chemical properties tests on raw and hydroretorted Indiana and hydroretorted Alabama, Kentucky, Michigan,
Ohio, and Tennessee shales. The results of these tests, presented 1990 Eastern Oil Shale Symposium, ${ }^{1}$ indicated that the storage of raw or spent shale in embankments would not result in any significant environmental impact. The objectives of the work described in this paper are to determine the effects of PFH processing and thermal posttreatment on the physical and chemical characteristics of raw and hydroretorted beneficialed Alabama shale. Posttreatment processes included combustion and agglomeration.

\section{Background}

To ensure that an industry based on producing oil from Eastern U.S. shales is environmentally sound, 
all aspects of the oil recovery process must be considered. The steps required to process beneficiated shale - the preferred feedstock for IGT's PFH process - in above-ground retorting facilities include excavation and mining, feedstock preparation and beneficiation, thermal processing (hydroretorting followed by combustion for power generation), tailings and spent-shale conditioning for disposal, disposal, and land reclamation. The quantities of shale (from either the Eastern or Western U.S.) that must be excavated and processed to yield the necessary oil can be substantial. For example, to produce 50,000 barrel/day of oil, a conventional thermal retorting plant may require as much as 210,000 ton/day of shale (eg. Eastern shale with a Fischer Assay of $10 \mathrm{gal} / \mathrm{ton})$. The plant would produce 178,500 tons of spent shale each day. Over the 25-year operating life of the plant, about $1.47 \times 10^{9}$ tons of spent shale would be generated and require disposal in an environmentally acceptable manner. A similar-sized plant based on PFH technology would require about 24,144 ton/day of beneficiated shale, produce 12,123 ton/day of hydroretorted shale, and accumulate $81.9 \times 10^{6}$ tons of hydroretorted and combusted shale (excluding tailings from the beneficiation plant) over the 25 -year plant operating life. ${ }^{2}$ According to Tolbert et al., the major environmental impact associated with shale processing is that of surface disposal of the spent shale. ${ }^{3}$

\section{Physical Properties}

The physical properties of raw and hydroretorted beneficiated shale dictate the geometry and size of embankments in which the raw and spent shale will be stored. Postretorting processing, such as combustion and agglomeration, will also affect the embankment characteristics. The angle of internal friction provides the maximum slope for the sides of the embankment to prevent sliding failure. The compactability and compressibility of the spent shale relate to the volume occupied by the shale at the optimum moisture content. The relative flow of water through the pile, which may affect leaching of environmentally sensitive metals, is related to the permeability or hydraulic conductivity. The Atterberg liquid and plastic limits are used to determine the moisture content of the solid sample (shale, soil, etc.) at the boundary between the liquid and plastic, and the plastic and semisolid states, respectively. Thermal conductivity dictates the rate at which hot shale from the retort or combustion process will cool to temperatures appropriate for moisturization.

During the 3-year DOE-sponsored program, IGT evaluated the physical, thermal, and chemical properties of raw and hydroretorted Indiana and hydroretorted Alabama, Kentucky, Michigan, Ohio, and Tennessee shales. A preliminary design for a storage embankment for bydroretorted shales from states was also prepared. ${ }^{1}$ That paper also summarized the work conducted by others on the physical and thermal properties of thermally retorted Eastern shale.

\section{Chemical Properties}

The chemical properties of shale determined during the program relate to the leaching of shale by precipitation on storage piles. Raw beneficiated shale will be exposed to weather during storage in stockpiles prior to hydroretorting. After hydroretorting and combustion, spent shale will also be exposed to weather in stockpiles prior to ultimate disposal. The most significunt environmental impacts could be realized during these exposures by the leaching of trace metals (and other components) into the shale water, which could then migrate into the groundwater. The test used to evaluate the leachability of solid samples is the U.S. Environmental Protection Agency (EPA) Toxicity Characteristic Leaching Procedure (TCLP). ${ }^{4}$

If the concentration of any trace element in the leachate from the TCLP test exceeds regulatory limits (Table 1), the material is classified as hazardous and must be disposed of in suitably constructed and monitored landfills. If the leachate is not effectively contained or collected, it could percolate down to the water table or combine with surface runoff to contaminate fresh water supplies. The sulfur content of the shale affects its leachability. A shale high in sulfur will yield leachate that is more acidic.

Table 1. EPA TCLP Limits For Metals ${ }^{4}$

\begin{tabular}{lc} 
& \multicolumn{2}{c}{ TCLP Leachate } \\
Element & Limit, mg/L \\
Arsenic & 5 \\
Barium & 100 \\
Cadmium & 1 \\
Chromium & 5 \\
Lead & 5 \\
Mercury & 0.2 \\
Selenium & 1 \\
Silver & 5
\end{tabular}

Thermal processing reduces the concentration of acidforming components in shale and yields leachate that is less acidic. Other elements of environmental importance (ie., nickel, thallium, and molybdenum) have been considered for inclusion on the list of priority metals. Regulations promulgated by the EPA in the future may include these elements as well as others determined to pose substantial environmental threats.

The leaching characteristics of raw and spent shales from both the Eastern and Western United States 
bave been the subject of numerous investigations ranging from laboratory extractions 5,6 to long-term lysimeter testing. ${ }^{7}$ Samples of combusted Western shale were tested by the University of Wyoming in a large-scale environmental chamber capable of simulating natural rainfall under carefully monitored conditions. ${ }^{8}$ Gilliam et al. ${ }^{5}$ reported significant decreases in the acid leachability of trace elements from shales that had been roasted in air at temperatures exceeding about $750^{\circ}$ to $850^{\circ} \mathrm{C}$. He attributed this to the phase change or sintering that the sample experienced at these temperatures.

\section{Experimental Equipment and Procedures}

\section{Shale Sample Preparation}

One sample of raw and three samples of thermally processed beneficiated Alabama shale were prepared for the physical and chemical properties tests. A bulk sample of shale was beneficiated at Michigan Technological University (Houghton) for the experimental tasks of the program. Samples of raw and hydroretorted beneficiated shale were obtained from a continuous bench-scale unit (BSU) test conducted at a temperature of $496^{\circ} \mathrm{C}$ in hydrogen and a pressure of $7 \mathrm{MPa}$ with a residence time of 26 minutes. The BSU equipment and test procedures have been described previously. 9 The particle size consist of the raw beneficiated feed shale was $-20+80$ mesh.

The hydroretorted and combusted (H\&C) beneficiated shale sample was obtained from tests conducted at IGT in another program task. The equipment and procedures used for the shale combustion tests were described by Roberts et al. ${ }^{10}$

The hydroretorted and agglomerated (H\&A) beneficiated shale sample was prepared with solids from the BSU test, which were subsequently agglomerated in a 50-mm diameter, laboratory-scale batch unit. The equipment and procedures used for shale agglomeration have also been described previously. ${ }^{1}$

Physical Properties

The physical properties tests were conducted by the Illinois Institute of Technology (IIT) Department of Civil Engineering. The physical properties of the samples of raw and processed PFH shales were determined using ASTM (American Society for Testing and Materials) standards or laboratory procedures developed by IIT. The tests and procedures, listed in Table 2, were conducted in the indicated order to minimize the impact on subsequent tests.

\section{Chemical Properties}

The toxic or non-toxic character of a solid sample is determined by subjecting it to the TCLP (EPA Meth- od 1s11). id the TCLP, a solid sample is mixed with 20 times its weight of an appropriate aqueous extraction fluid (depending upon alkalinity) for 18 hours.

Table 2. Sequence and Physical Property Tests Used For Raw and Thermally Processed Beneficiated Shale Samples

\begin{tabular}{clll} 
Sequence & Physical Property & Test/ASTM Standard \\
\cline { 1 - 3 } & Particle Size & D 421-85 \\
2 & Permeability & D 2434-74 \\
3 & Thermal Conduct. & IIT Laboratory Test \\
4 & Consolidation/ & \\
& Compressibility & D 2435-80 \\
5 & Shear Strength & D 3080-72 \\
6 & Compactability & D 698-78 (Harv. min.) \\
7 & Atterberg Liquid & \\
& \& Plastic Limit & D 4318-84 \\
8 & Specific Gravity & D 854-83
\end{tabular}

After the extraction period, the concentration of metais (listed in Table 1) in the leachate (plus volatile and nonvolatile organic compounds) are determined. If the concentration of any metal (or organic compound) in the leachate exceeds the regulatory limit, the material is said to exhibit a toxic character and is classified as a hazardous waste. The solid must then be disposed of in suitably constructed and monitored landfills. Because the current work focused on shale metals, the leachate was not analyzed for organic compounds.

TCLP tests were conducted on raw beneficiated, hydroretorted (PFH), hydioretorted and combusted (H\&C), and hydroretorted and agglomerated (H\&A) Alabama shale samples retumed from IIT after the physical properties tests were completed. If the results of TCLP tests on H\&C and H\&A shales were similar, the spent shale could be disposed of without further processing.

\section{Discussion of Results}

\section{Physical Properties}

Overall, the physical properties of the four beneficiated and thermally processed shale samples showed considerable variability. The results of particle size, thermal conductivity, permeability, consolidation (compressibility), shear strength, compactability, and Atterberg Liquid and Plastic limit tests are presented in Tables 3 through 7.

The particle size distributions (Table 3) for the raw and hydroretorted beneficiated shale samples were quite similar prior to compaction. About 85 percent of the samples were $-10+50$ mesh. The hydroretorted and combusted (H\&C) sample had about 69 
Table 3. Particle Size Distribution of Raw and Processed Beneficiated Alabama Shale (Before Compaction)

\begin{tabular}{|c|c|c|c|c|}
\hline \multirow[b]{2}{*}{ Sample } & \multirow[b]{2}{*}{ Raw } & \multirow[b]{2}{*}{ Hydroretorted } & \multicolumn{2}{|c|}{ Hydroretorted \& } \\
\hline & & & Combusted & Agqlomerate \\
\hline \multicolumn{5}{|c|}{ Particle Size Distribution, wt \% } \\
\hline+10 & 0.0 & 0.0 & 0.0 & 0.0 \\
\hline$-10+20$ & 21.4 & 12.0 & 0.2 & 25.0 \\
\hline$-20+40$ & 44.8 & 55.3 & 36.7 & 28.7 \\
\hline$-40+50$ & 17.8 & 18.0 & 31.9 & 10.9 \\
\hline$-50+80$ & 9.8 & 9.5 & 24.2 & 9.2 \\
\hline$-80+100$ & 2.6 & 1.9 & 3.1 & 3.0 \\
\hline$-100+200$ & 2.0 & 2.3 & 3.3 & 11.8 \\
\hline$-200+$ pan & 1.6 & 1.0 & 0.6 & 11.4 \\
\hline Total & 100.0 & 100.0 & 100.0 & 100.0 \\
\hline
\end{tabular}

Table 4. Thermal Conductivities and Permeabilities of Raw and Processed Beneficiated Alabama Shale

Sample

Thermal Conductivity,

$$
\mathrm{W} / \mathrm{m}-\mathrm{K}
$$

$$
\text { (Btu/h-ft- }{ }^{\circ} \mathrm{F} \text { ) }
$$

At Density, $\mathrm{g} / \mathrm{cm}^{3}$

Permeability,

$$
\mathrm{k}_{20}, \mathrm{~cm} / \mathrm{s}
$$$$
\text { At Density, } \mathrm{g} / \mathrm{cm}^{3}
$$

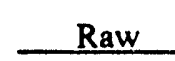

Hydroretorted

$\begin{array}{rr}0.67 & 0.08 \\ (0.39) & (0.05)\end{array}$

(0.05)

0.67

0.75

3.2E-3

0.99

2.74E-3

0.88
Hydroretorted \&

Combusted Agqlomerated
0.11
$(0.06)$
0.06
$(0.04)$
0.58
0.72

2.94E-3

4.8E-4

0.96

\begin{tabular}{|c|c|c|c|c|}
\hline \multirow{2}{*}{ Sample } & \multirow[b]{2}{*}{ Raw } & \multirow[b]{2}{*}{ Hydroretorted } & \multicolumn{2}{|c|}{ Hydroretorted \& } \\
\hline & & & Combusted & Agglomerated \\
\hline \multicolumn{5}{|c|}{ Consolidation Void Ratio, Vol. Void/Vol. Solid } \\
\hline Initial & 1.17 & 0.88 & 0.76 & 1.24 \\
\hline Final & 0.65 & 0.44 & 0.36 & 0.69 \\
\hline \multicolumn{5}{|l|}{ Density, $\mathrm{g} / \mathrm{cm}^{3}$} \\
\hline Initial & 1.36 & 0.96 & 1.19 & 1.38 \\
\hline Final & 1.80 & 1.26 & 1.53 & 1.83 \\
\hline \multicolumn{5}{|c|}{ Consolidation factors } \\
\hline $\mathrm{C}_{\mathrm{c}}^{\prime}$ & 0.046 & 0.047 & 0.021 & 0.091 \\
\hline $\mathrm{C}_{\mathrm{c}}$ & 0.25 & 0.17 & 0.17 & 0.22 \\
\hline \multirow{2}{*}{\multicolumn{5}{|c|}{$\begin{array}{l}\text { Shear Strength } \\
\text { Angle of Internal }\end{array}$}} \\
\hline & & & & \\
\hline Friction, ${ }^{\circ}$ & 37.2 & 26.0 & 27.0 & 32.8 \\
\hline $\begin{array}{c}\text { Cohesion (c), kPa } \\
\text { (psi) }\end{array}$ & $\begin{array}{r}0.0 \\
(0.0)\end{array}$ & $\begin{array}{l}17.2 \\
(2.5)\end{array}$ & $\begin{array}{r}5.5 \\
(0.8)\end{array}$ & $\begin{array}{r}0.0 \\
(0.0)\end{array}$ \\
\hline At Density, $\mathrm{g} / \mathrm{cm}^{3}$ & 0.99 & 0.85 & 0.79 & 1.23 \\
\hline \multicolumn{5}{|c|}{4} \\
\hline
\end{tabular}

Table 5. Consolidation and Shear Strength Characteristics of Raw and Processed Beneficiated Alabama Shale 
Table 6. Compactability Characteristics of Raw and Processed Beneficiated Alabama Shale

\begin{tabular}{|c|c|c|c|c|}
\hline \multirow[b]{2}{*}{ Sample } & \multirow[b]{2}{*}{ Raw } & \multirow[b]{2}{*}{ Hydroretorted } & \multicolumn{2}{|c|}{ Hydroretorted \& } \\
\hline & & & Combusted & Agglomerated \\
\hline \multicolumn{5}{|c|}{$\begin{array}{c}\text { Compsction Test Results (Harvard Miniature) } \\
\text { Optimum Moisture Content (OMC), wt } \%\end{array}$} \\
\hline & 26.0 & 25.0 & 25.0 & 10.0 \\
\hline \multicolumn{5}{|c|}{ Maximum Dry Density (MDD), $\mathrm{g} / \mathrm{cm}^{3}$} \\
\hline & 1.23 & 1.11 & 0.96 & 1.19 \\
\hline \multicolumn{5}{|c|}{ Particle Size Distribution, wt \% (after compaction) } \\
\hline+10 & 0.0 & 0.0 & 0.0 & 0.0 \\
\hline$-10+20$ & 23.0 & 16.0 & 15.0 & 12.1 \\
\hline$-20+40$ & 24.0 & 21.0 & 20.0 & 25.5 \\
\hline$-40+50$ & 14.0 & 11.0 & 14.0 & 12.2 \\
\hline$-50+80$ & 16.0 & 12.0 & 15.0 & 12.2 \\
\hline$-80+100$ & 14.0 & 7.0 & 6.0 & 4.5 \\
\hline$-100+200$ & 5.0 & 12.0 & 9.0 & 15.2 \\
\hline$-200+$ pan & 4.0 & 21.0 & 21.0 & 18.3 \\
\hline Total & 100.0 & 100.0 & 100.0 & 100.0 \\
\hline
\end{tabular}

Table 7. Atterberg Liquid and Plastic Limit For Raw and Processed Beneficiated Alabanza Shale

\begin{tabular}{|c|c|c|c|c|}
\hline \multirow[b]{2}{*}{ Sample } & \multirow[b]{2}{*}{ Raw } & \multirow[b]{2}{*}{ Hydroretorted } & \multicolumn{2}{|c|}{ Hydroretorted \& } \\
\hline & & & Combusted & Agglomerated \\
\hline Liquid Limit, \% & 31.8 & 32.4 & 48.0 & 25.3 \\
\hline Plastic Limit, \% & 16.5 & 18.5 & 23.2 & 14.6 \\
\hline Plasticity Index, \% & 15.3 & 13.9 & 24.8 & 10.7 \\
\hline Flow Index & -10.9 & -6.5 & -18.3 & -14.5 \\
\hline $\begin{array}{l}\text { Specific } \\
\text { Gravity }\left(G_{s}\right), g / \mathrm{cm}^{3}\end{array}$ & 1.84 & 1.64 & 2.40 & 2.22 \\
\hline
\end{tabular}

percent in the $-10+50$ mesh particle size range. The hydroretorted and agglomerated (H\&A) sample was crushed by hand at IIT to -10 mesh for the physical properties tests, which explains the relatively high fraction of -100 mesh particles in this sample.

The thermal conductivity (TC) of the raw beneficiated shale sample was $0.67 \mathrm{~W} / \mathrm{m}-\mathrm{K}$ (Table 4). Hydroretorting this sample reduced the TC to $0.08 \mathrm{~W} / \mathrm{m}-\mathrm{K}$. Combustion of the hydroretorted shale sample resulted in a slight increase in TC (compared to that of the hydroretorted sample) to $0.11 \mathrm{~W} / \mathrm{m}-\mathrm{K}$. Agglomeration of the hydroretorted shale sample reduced the TC slightly to $0.06 \mathrm{~W} / \mathrm{m}-\mathrm{K}$. For comparison, in previous work, IGT determined the TC of a sample of hydroretorted Alabama shale to be $0.21 \mathrm{~W} / \mathrm{m}-\mathrm{K} .^{1}$

The permeability $\left(\mathrm{k}_{20}\right)$ of the raw beneficiated shale sample was $3.2 \times 10^{-3} \mathrm{~cm} / \mathrm{s}$. Hydroretorting the bene- ficiated sample reduced the permeability somewhat to $2.74 \times 10^{-3} \mathrm{~cm} / \mathrm{s}$. Combustion of the hydroretorted sample reduced the permeability by an order of magnitude to $4.8 \times 10^{-4} \mathrm{~cm} / \mathrm{s}$. The permeability of the H\&A sample $\left(2.94 \times 10^{-3} \mathrm{~cm} / \mathrm{s}\right)$ was essentially the same as that of the hydroretorted sample. It should be noted that size reduction of the H\&A sample by IIT may have affected the results of the permeability test somawhat. The permeability of a sample of hydroretorted Alabama shale was determined to be $1.34 \times 10^{-2} \mathrm{~cm} / \mathrm{s}^{1}$

The results of consolidation tests (Table 5) showed that the initial void ratio (volume of voids per volume of solids) of the raw sample was 1.17 , which decreased with hydroretorting to 0.88 and with combustion to 0.76 . The void ratio of the H\&A sample (1.24) was higher than that of the raw beneficiated shale sample. After consolidation, the H\&C shale 
sample had the lowest void ratio (0.36). The compacted bulk density of the samples ranged from about $1.26 \mathrm{~g} / \mathrm{cm}^{3}$ for the hydroretorted shale to $1.83 \mathrm{~g} / \mathrm{cm}^{3}$ for the H\&A shale, which was similar to that of the raw beneficiated shale sample $\left(1.80 \mathrm{~g} / \mathrm{cm}^{3}\right)$. The compacted void ratio and bulk density of a sample of hydroretorted Alabama shale were determined previously ${ }^{1}$ to be 0.68 and $1.55 \mathrm{~g} / \mathrm{cm}^{3}$, respectively.

The factors, $\mathrm{C}_{\mathrm{c}}$ ' and $\mathrm{C}_{\mathrm{c}}$, are obtained from the consolidation tests. $C_{c}$ ' is an indication of the rebound (springiness) of the sample after consolidation - a higher value for $C_{c}$ ' indicates a higher rebound. $C_{c}$ is a measure of the rate at which the sample consolidates. A sample with a high $C_{c}$ will consolidate at a faster rate than one with a low value of $C_{c}$.

The angle of internal friction was determined to be $37.2^{\circ}$ for raw beneficiated shale and $26.0^{\circ}$ and $27.0^{\circ}$ for the hydroretorted and H\&C shale samples, respectively. The angle of internal friction for the H\&A sample was $32.8^{\circ}$. The cohesion (c) was $0.0 \mathrm{kPa}$ for the raw beneficiated shale and 17.2 and $27.0 \mathrm{kPa}$ for the hydroretorted and H\&C shale samples. The cohesion for the H\&A sample was the same as that of the raw sample. The angle of internal friction and cohesive strength for a sample of bydroretorted Alabama shale were previously determined to be $40.9^{\circ}$ and 0.0 $\mathrm{kPa}$, respectively. ${ }^{1}$

The results of the compactability tests are presented in Table 6. The compactability tests were conducted using a Harvard miniature mold. This mold has a $3.3-\mathrm{cm}$ diameter, a height of $7.2 \mathrm{~cm}$, and a capacity of $61.2 \mathrm{~cm}^{3}$. The Harvard miniature mold is used when the quantity of sample is limited. The standard mold for this procedure is $10.2 \mathrm{~cm}$ in diameter, 11.6 $\mathrm{cm}$ tall, and has a capacity of $944 \mathrm{~cm}^{3}$. Optimum moisture contents (OMC) for the raw, hydroretorted, and H\&C samples of beneficiated shale were about 25 percent. The OMC of the H\&A sample was 10 percent. The maximum dry density (MDD at the OMC) decreased from $1.23 \mathrm{~g} / \mathrm{cm}^{3}$ for the raw sample to $1.11 \mathrm{~g} / \mathrm{cm}^{3}$ for the hydroretorted sample to 0.96 $\mathrm{g} / \mathrm{cm}^{3}$ for the H\&C sample. The MDD was determined to be $1.19 \mathrm{~g} / \mathrm{cm}^{3}$ for the H\&A sample. The OMC and MDD of a sample of hydroretorted Alabama shale were determined ${ }^{1}$ to be 22 percent and $1.36 \mathrm{~g} / \mathrm{cm}^{3}$, respectively.

The results show that the hydroretorted samples (including $\mathrm{H} \& \mathrm{C}$ and $\mathrm{H} \& A$ ) experienced particle size reduction during the compaction procedure. The fines (-100 mesh) content in the hydroretorted sample increased from 3.3 (See Table 3 ) before to 33.0 percent after compaction. In the $\mathrm{H} \& \mathrm{C}$ sample, the fines content increased from 3.9 to 30.0 percent. The fines content of the H\&A sample increased the least, from 23.2 to 33.5 percent, indicating a higher resistance to fracture.

The results of the Atterberg Liquid and Plastic Limits tests are presented in Table 7. Per the ASTM definition, the Liquid Limit is the water content of a sample, expressed as a percentage of the dry sample weight, at the boundary between the liquid and plastic states. It is arbitrarily defined as the water content at which two halves of a soil cake will flow together for a distance of $1 / 2$ inch along the bottom of a groove separating the two halves, when the sample cup is dropped 25 times for a distance of $1 \mathrm{~cm}$ at a rate of two drops per second. The sample cup is a rounded brass bowl, $93.3 \mathrm{~mm}$ in diameter and $27.1 \mathrm{~mm}$ deep. Typically, tests at three different water contents are needed to determine the Liquid Limit. The results of the three Liquid Limit tests are plotted on semilog paper with the water content on the ordinate and the number of drops required on the abscissa (log scale). The water content at which the line intercepts the 25drop value is the Liquid Limit. The slope of the line is defined as the Flow Index. For materials that exhibit the same Liquid Limit value, a low Flow Index (shallow slope) means that the sample will be in the liquid state with less liquid addition than a sample with high Flow Index (steep slope). For considerations of slope stability in embankments, a high Liquid Limit and high Flow Index value are preferred.

The Plastic Limit is defined as the water content of a sample, also expressed as a percentage of the dry sample weight, at the boundary between the plastic and semisolid states. It is arbitrarily defined as the lowest moisture content at which the soil sample can be rolled (by hand) into threads $3.2 \mathrm{~mm}$ in diameter without the threads breaking into pieces. The Plasticity Index is defined as the difference between the Liquid and Plastic Limits. For slope stability in embankments, a high Plastic Limit and high Plasticity Index value are preferred.

For example, the liquid and plastic limits for sand are both zero $(0)$. Therefore, sand will behave like a liquid (quicksand in the extreme) with little moisture addition. The liquid limit for clay ranges from 10 to 100; the plastic limit for clay ranges even higher, depending upon the clay composition.

The results show that the Liquid Limits for the raw and hydroretorted beneficiated shale samples are quite similar at about 32 percent. The H\&C sample exhibits the highest Liquid Limit value (48.0 percent); the H\&A sample the lowest (25.3 percent). The H\&C sample also has the highest Plastic Limit (23.2 
percent) and Plasticity Index (24.8 percent) of the other samples and the highest Flow Index (-18.3). For storage in embankments and to ensure slope stability, the H\&C sample exhibits characteristics that are more desirable than those of the other samples. However, because the Plasticity Index values fali within a fairly narrow range of about 10 to 25 , the other sample characteristics are not detrimental to slope stability.

\section{Chemical Properties}

The results of the TCLP tests conducted on the shale samples are presented in Table 8 . The results show that for the raw, hydroretorted, H\&C, and H\&A beneficiated shale samples, neither silver, lead, nor mercury were leached at levels above the detection limit of the analytical technique used. Selenium levels were about 10 percent of the TCLP limit and all other elements were leached at less than 2 percent of the TCLP limit. All eight elements were leached from the feed and residue shales at levels below the TCLP regulatory limits. Therefore, these samples do not exhibit the toxicity characteristic.

In Figures 1 through 4, the ratio of the concentration of each element in the shale leachate to its regulatory (TCLP) limit is presented for different thermal processing steps. If the metal concentration was less than the detection limit, the detection limit was used for the figures.

Figure 1 shows the effect of hydroretorting on the leachability of metals from beneficiaied shale. In the case of cadmium, chromium, and selenium, hydroretorting apparently reduces leachability. However, the leachability of arsenic appears to be somewhat enhanced by hydroretorting. The ratios for all elements are less than 0.04, except for those of selenium, which are less than 0.13 .

Figure 2 compares the effects of hydroretorting and subsequent thermal processing $r \downarrow$ metal leachability. Data for raw beneficiated shale is included for completeness. The results show that combusting the hydroretorted beneficiated shale does not significantly affect metal leachability except for that of selenium. Combustion reduced the leachate ratio for selenium from 0.096 (hydroretorted shale) to 0.026 . Leachability ratios of other metals were unaffected or based on the analytical detection limit. Agglomeration of the hydroretorted sample further reduced the selenium ratio compared to that of the combusted sample from 0.026 to 0.013 (detection limit). Agglomeration also reduced the ratio for arsenic from 0.0156 (combusted shale) to 0.0014 .
Figures 3 and 4 compare the effects of beneficiation and subsequent hydroretorting or thermal processing on metal leachability. The TCLP data for hydroretorted raw Alabama shale were from a previous program at IGT.' Figure 3 shows the effect of beneficiation on the leaching characteristics of hydroretorted shale. The results show that, in general, beneficiation does not significantly affect metal leachability. However, the data do show that hydroretorted beneficiated shale releases roughly 10 times more arsenic and selenium during the TCLP than does hydroretorted raw shale. The leachate/TCLP limit ratios for samples of raw and beneficiated shales that have been hydroretorted and then agglomerated are shown in Figure 4. The ratios are similar and most are based on the analytical detection limits. The ratio for cadmium in agglomerated beneficiated shale was 0.12 ; that for the agglomerated raw shale was 0.01 (detection limit). These results should be confirmed.

\section{Embankment Design}

General guidelines for designing an embankment for storing raw, hydroretorted, or H\&C or H\&A shale are as follows. To ensure stability, the slope of the embankment should not exceed a rise/run ratio of 0.5 $\left(\sim 26^{\circ}\right)$. A material cohesion of $0 \mathrm{kPa}$ should be assumed. Combusted shale could be compacted to a density of $0.96 \mathrm{~g} / \mathrm{cm}^{3}$ and a moisture content of 25 weight percent. Agglomerated shale could be compacted to a density of $1.19 \mathrm{~g} / \mathrm{cm}^{3}$ and a moisture content of 10 weight percent. Reclamation could be initiated with a surficial coverage of top soil (or overburden) of about 0.3 to 1 meter in thickness. Because none of the thermally treated samples exhibit the toxicity characteristic, all could be stored in ordinary surface or landfills.

\section{Conclusions}

The physical, chemical, and thermal properties of raw, hydroretorted, hydroretorted and combusted (H\&C), and hydroretorted and agglomerated (H\&A) beneficiated Alabama shale samples were determined. Based on the results, the following conclusions and observations can be made:

- Thermal conductivity ranged from 0.06 to 0.11 $\mathrm{W} / \mathrm{m}-\mathrm{K}$ for thermally processed shales, and was $0.67 \mathrm{~W} / \mathrm{m}-\mathrm{K}$ for raw beneficiated Alabama shale.

- Permeabilities of the shale samples were in the range of $10^{-3} \mathrm{~cm} / \mathrm{s}$; that of the $\mathrm{H} \& \mathrm{C}$ shale sample was lowest at about $10^{-4} \mathrm{~cm} / \mathrm{sec}$. 
Table 8. Results of TCLP Tests Conducted on Samples of Raw and Processed Beneficiated Alabama Shale

\begin{tabular}{|c|c|c|c|c|c|}
\hline \multirow{2}{*}{ Sample } & & \multirow[b]{2}{*}{ Raw } & \multirow[b]{2}{*}{ Hydroretorted } & \multicolumn{2}{|c|}{ Hydroretorted \& } \\
\hline & & & & Combusted & Agolomerated \\
\hline \multicolumn{6}{|c|}{$\begin{array}{l}\text { TCLP Extract Analysis: Maximum } \\
\text { Allowable } \\
\text { Conc. }\end{array}$} \\
\hline $\begin{array}{l}\text { Element } \\
\text { Arsenic }\end{array}$ & 5 & 0.0023 & 0.081 & 0.078 & 0.0069 \\
\hline Barium & 100 & 0.073 & 0.082 & 0.034 & 0.085 \\
\hline Cadmium & 1 & 0.038 & $<0.02$ & $<0.02$ & 0.12 \\
\hline Chromium & 5 & 0.13 & $<0.05$ & $<0.05$ & $<0.05$ \\
\hline Lead & 5 & $<0.2^{*}$ & $<0.2$ & $<0.2$ & $<0.2$ \\
\hline Mercury & 0.2 & $<0.005$ & $<0.005$ & $<0.001$ & $<0.001$ \\
\hline Selenium & 1 & 0.13 & 0.096 & 0.026 & $<0.013$ \\
\hline Silver & 5 & $<0.05$ & $<0.05$ & $<0.05$ & $<0.05$ \\
\hline
\end{tabular}

" " <" indicates detection limit of the analytical technique used.

- Consolidation test results show that the void ratio of the samples could be reduced by about 50 percent. After consolidation, the void ratio of the H\&C sample was 0.36 .

- The angle of internal friction was $37.2^{\circ}$ for the raw sample, $26.0^{\circ}$ for the hydroretorted sample, $27.0^{\circ}$ for the H\&C sample, and $32.8^{\circ}$ for the H\&A sample. Cohesive strengths were similar for the raw and $\mathrm{H} \& A$ shale samples $(0 \mathrm{kPa})$.

- Beneficiated shale can be compacted to a density of $1.23 \mathrm{~g} / \mathrm{cm}^{3}$ at an optimum moisture content of 26 percent. The H\&A shale can be compacted to $1.19 \mathrm{~g} / \mathrm{cm}^{3}$ at an optimum moisture content of 10 percent.

- Embankments with processed beneficiated shale can be constructed safely a slope of $26.5^{\circ}$ (1:2 rise/run).

- The results of leaching tests conducted with raw and thermally processed beneficiated shale samples showed that all samples passed the TCLP test.

Therefore, spent shale from the PFH process can be safely disposed of in ordinary landfills.

\section{Recommendations}

Large-scale and long-term evaluations should be conducted with embankments of hydroretorted and spent beneficiated shales on design, slope stability, and reclamation. Large-scale lysimeter tests should be conducted on bulk samples of hydroretorted and spent beneficiated shale to determine long-term leaching characteristics. Other elements, such as $\mathrm{Ni}$ and Mo, should be analyzed in the leachate from TCLP tests.

\section{Acknowledgments}

The authors acknowledge the U.S. DOE (Laramie Project Office) for sponsoring the work conducted in this program. The efforts of Mr. Anshu Baikal for performing the physical properties tests at IIT and Mr. Zongxuan Hong at IGT for conducting the shale agglomeration tests at IGT are also acknowledged.

\section{References}

1. Mensinger, M. C., and Saxena, S. K., "Physical and Thermal Properties and Leachability of Eastem Oil Shales Hydroretorted in a Pressurized Fluidized Bed," Fuel, Vol. 70, Nov. 1991, pp. 1285-1292.

2. Organic components plus sulfur are assumed to be completely converted during combustion. Disposal amount is based on 330 day/year operation for 25 years.

3. Tolbert, V. R., Eddlemon, G. K., Ketelle, R. H. et al., "A Preliminary Assessment of Environmental Impacts of Obtaining Oil From Chattanooga Shale," Proceedings 1981 Eastern Oil Shale Symposium, Nov. 15-17, 1981, Lexington, $\mathrm{KY}$, Institute for Mining and Minerals Research, pp. 349-356.

4. Federal Register, Thursday March 29, 1990, Part II Environmental Protection Agency, 40 CFR Part 261 el al., pp. 11845-11846.

5. Gilliam, T. M., Canon, R. M., Ryan, A. D. et al., "Metal Recovery from Eastern Oil Shale," Proceedings 1981 Eastern Oil Shale Symposium, Nov. 15-17, 1981, Lexington, KY, Institute for Mining and Minerals Research, pp. 323-329. 
6. Spiewak, I., Gilliam, T. M., and Silverman, M. D., "Development of Processes for Recovery of Minerals from Eastern Shale, " IGT's Symposium on Synthetic Fuels From Oil Shale II, Nashville, TN, Oct. 26-29, 1981, pp. 97-122.

7. Robl, T. L., Barron, L. S., Schramm, W. et al., "Final Summary of Data from the Hope Creek Field Leaching Study," Proceedings 1988 Eastern Oil Shale Symposium, Nov. 30-Dec. 2, 1988, Lexington, KY, Institute for Mining and Minerals Research, pp. 115-121.

8. Skinner, Q. D., Reeves, T. L., Turner, J. R. et al., "Simulated Climate and Shale Pile Response Within a Large-Scale Environmental Chamber
Developed in Wyoming," Proceedings 1989 Easten Oil Shale Symposium, Nov. 15-17, 1989, Lexington, KY, Institute for Mining and Minerals Research, pp. 386-393.

9. Mensinger, M. C., Rue, D. M., and Roberts, M. J., "Environmental Data From Bench-Scale Pressurized Fluidized-Bed Hydroretorting of Eastern Oil Shales," Fuel, Vol. 71, Dec. 1992, pp. 1377-1383.

10. Roberts, M. J., Rue, D. M., and Lau, F. S., "Evaluation of Combustion of Hydroretorted Alabama Oil Shale," Paper presentod at the 1992 Eastern Oil Shale Symposium, Lexington, Ky., Nov. 17-20, 1992.

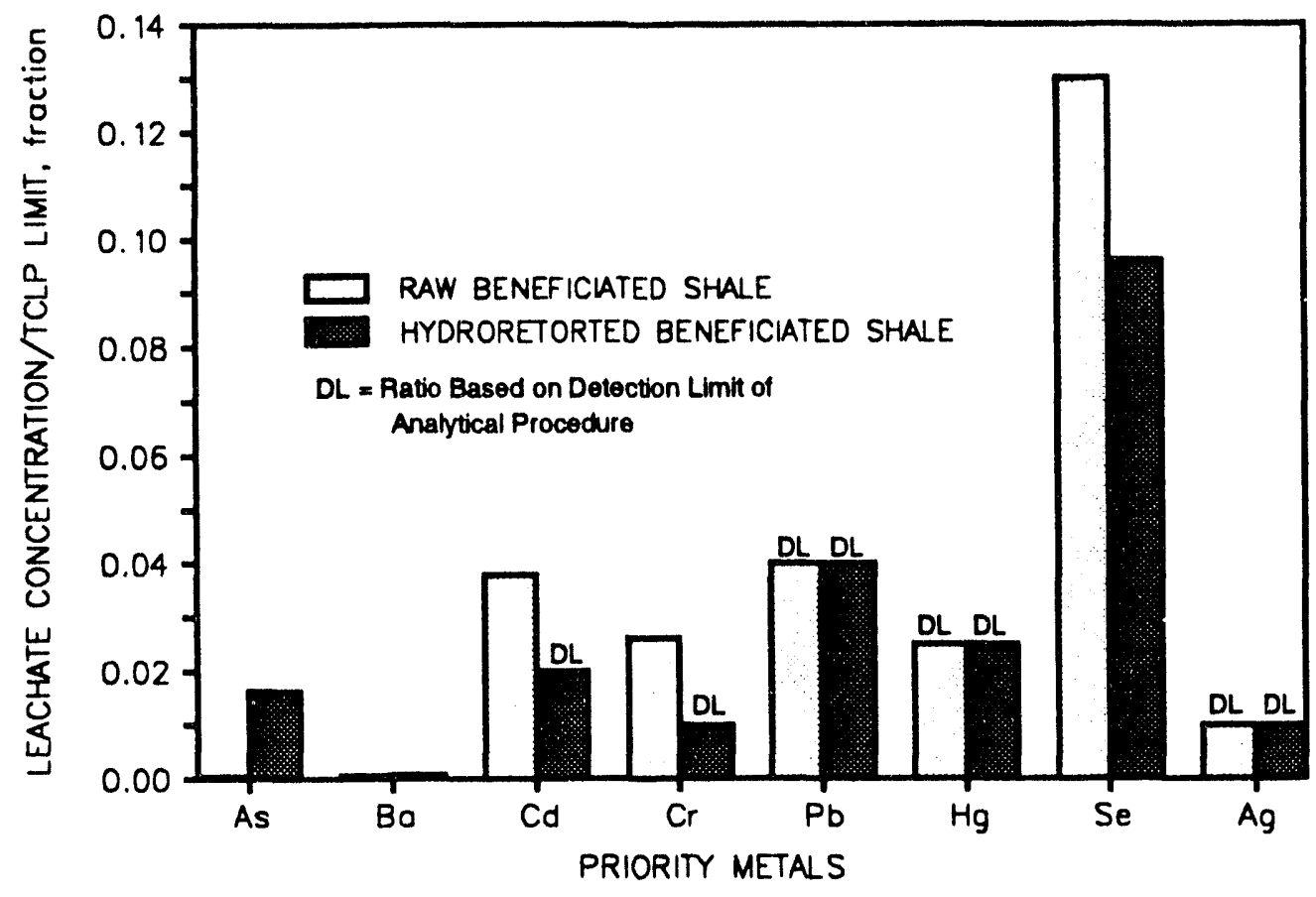

Figure 1. Effect of hydroretorting on the leaching characteristics of beneficiated Alabama shale 


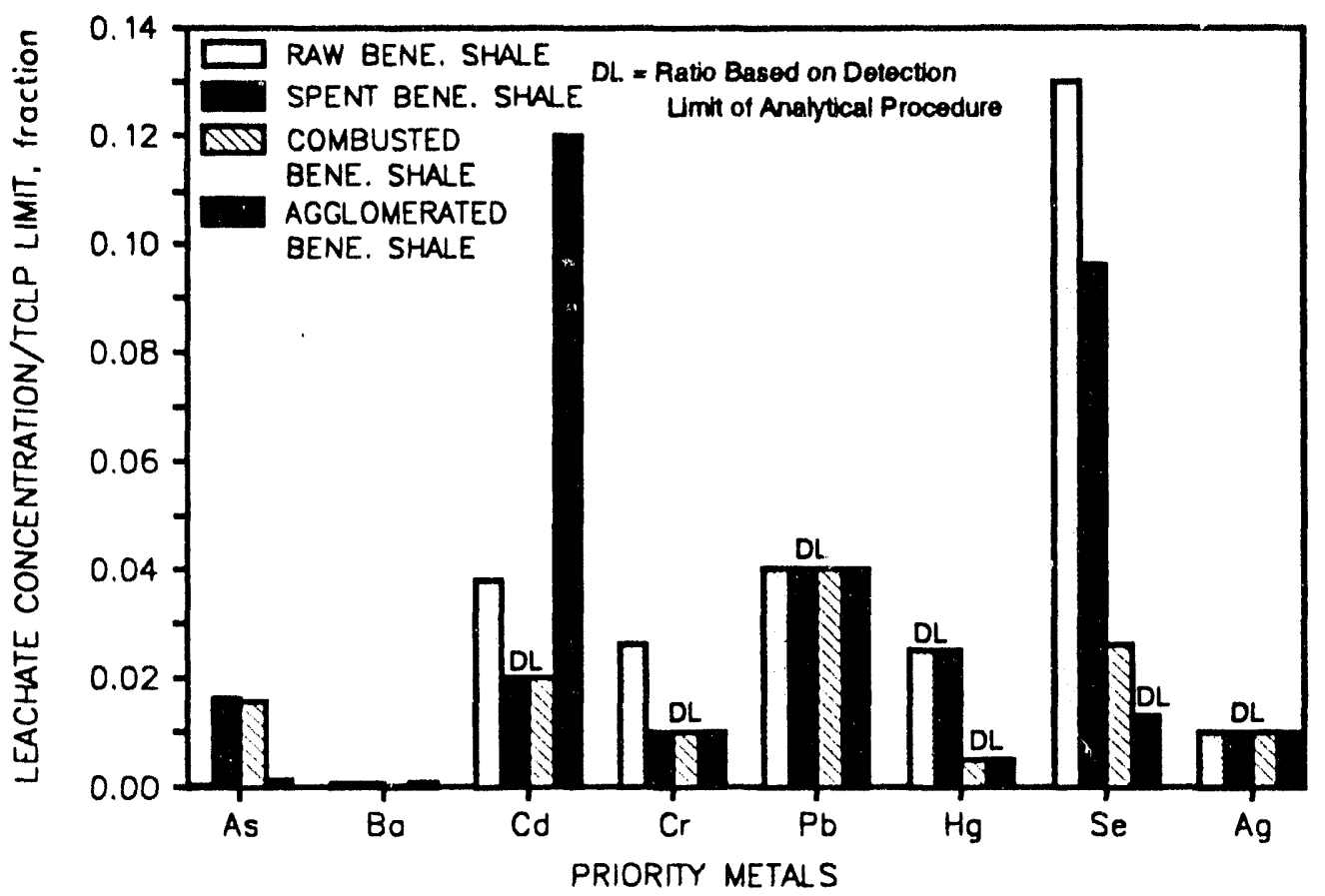

Figure 2. Effect of thermal processing on the leaching characteristics of beneficiated Alabama shale

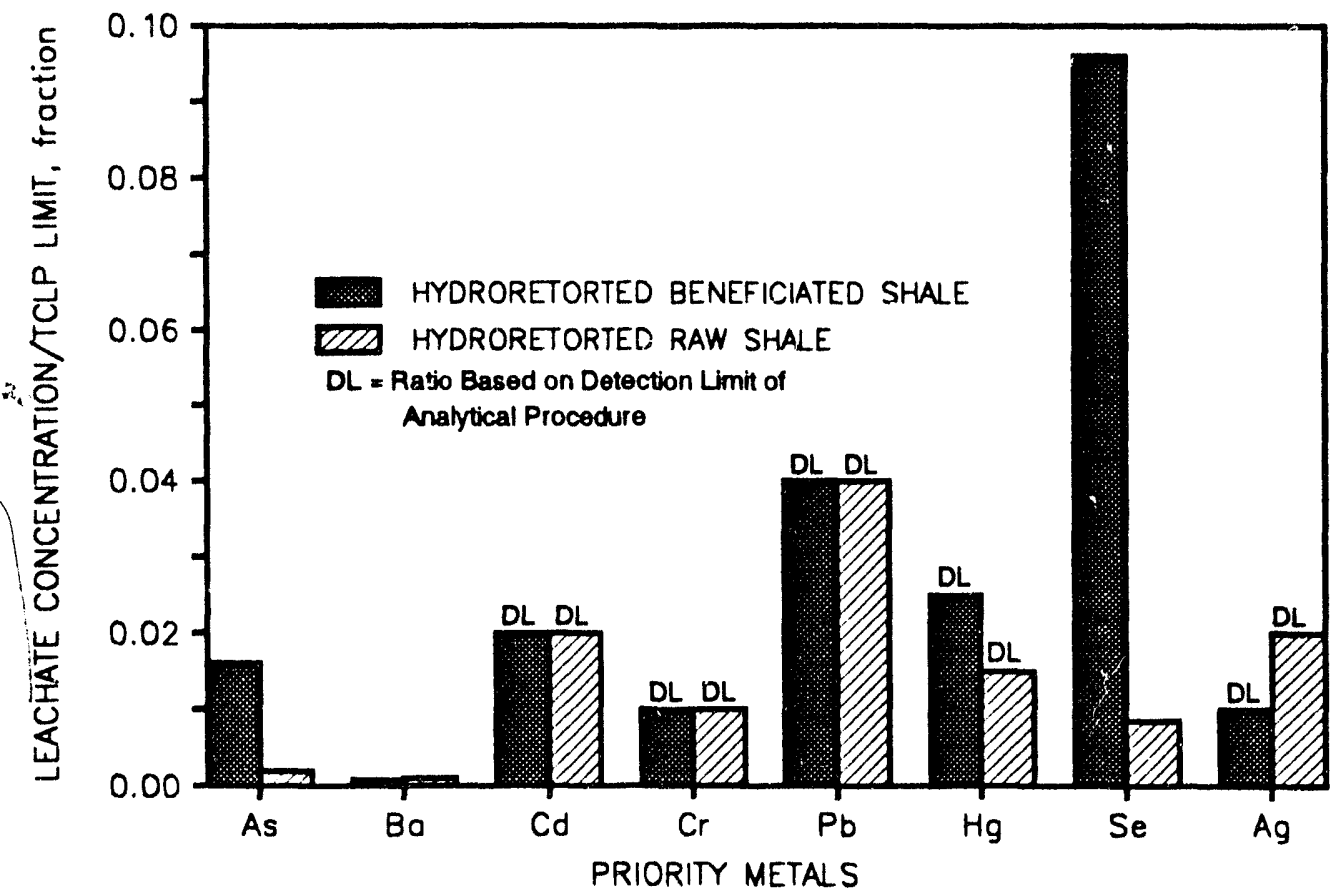

Figure 3. Effect of beneficiation on the leaching characteristics of hydroretorted Alabama shale 


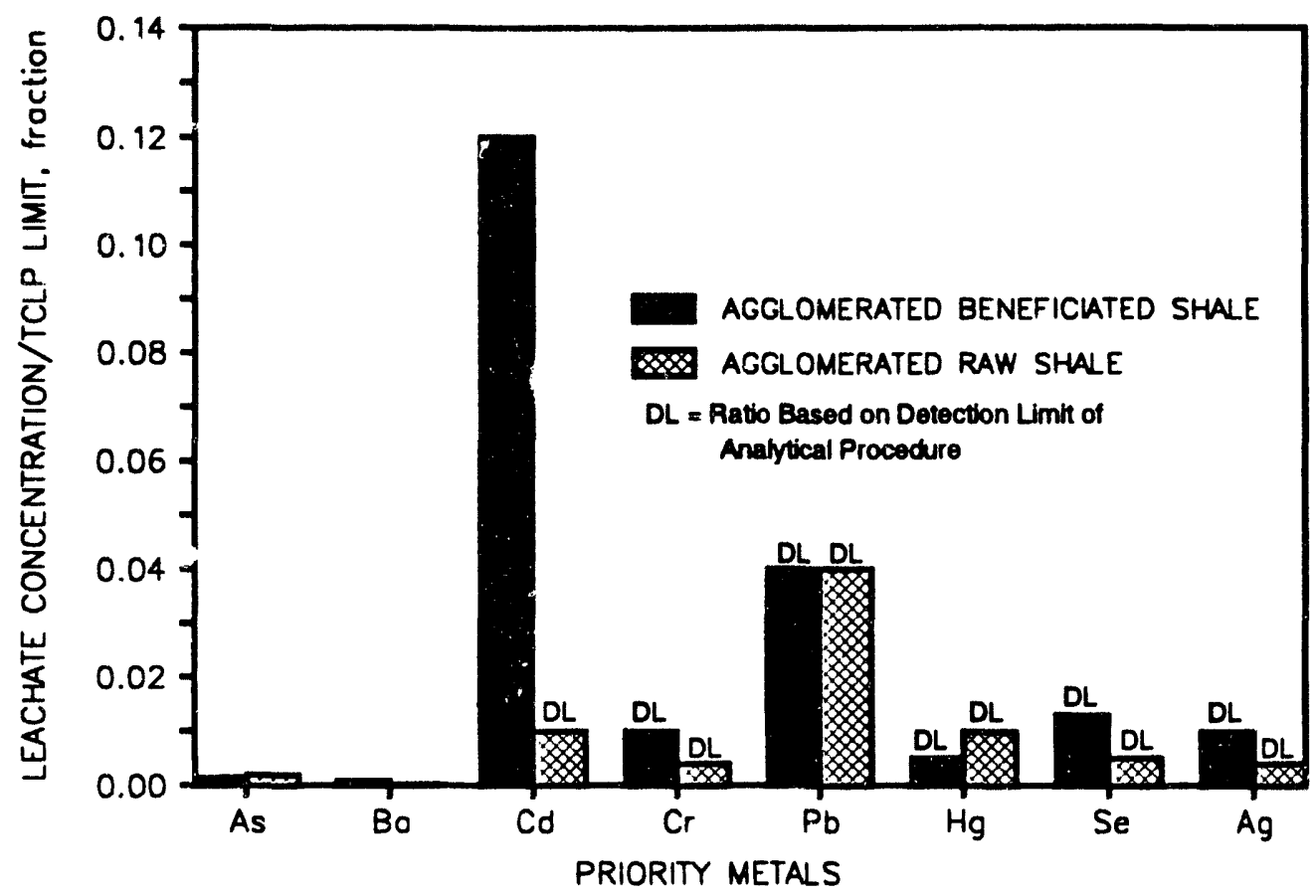

Figure 4. Effect of beneficiation on the leaching characteristics of agglomerated Alabama shale 

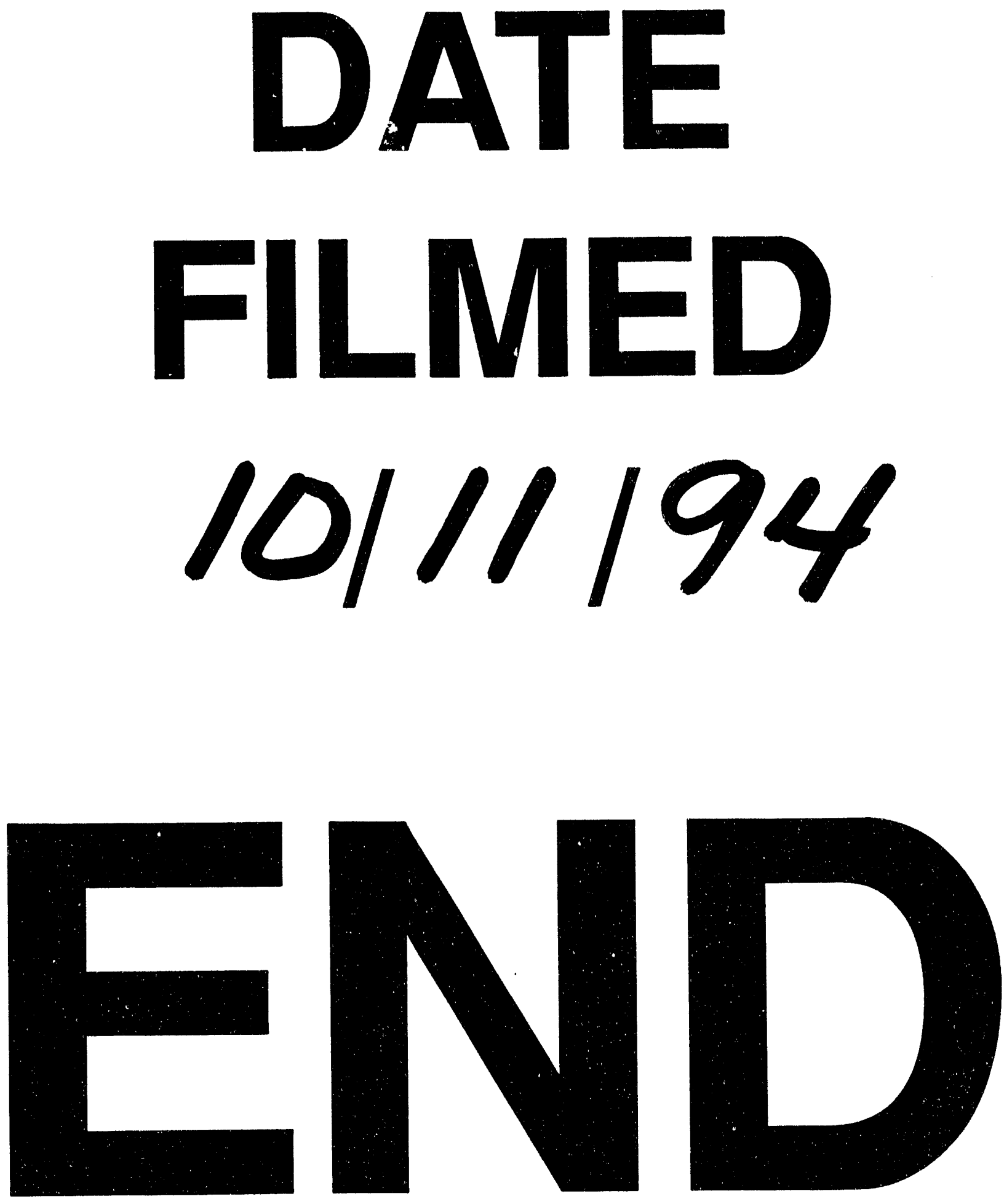
